\title{
THE IMPACTS OF INSTITUTIONS, OPENNESS AND MACROECONOMIC STABILITY ON ECONOMIC GROWTH: A PANEL DATA ANALYSIS ON MIDDLE INCOME COUNTRIES ${ }^{1}$
}

\author{
Fatih KAPLAN $^{*} \quad$ Sevda YAPRAKLI ${ }^{* *}$
}

\begin{abstract}
This study aims to analyze the impacts of indirect determinants such as institutions, trade-financial openness and macroeconomic stability on economic growth in 48 middle income countries. With this purpose, the impacts of the ten indicators in total belonging to the aforesaid variables for the term of 2002-2011 on economic growth are econometrically analyzed by using panel data analyses. According to the results of the analysis, institutions (political stability and absence of violence, regulatory quality and rule of law), trade and financial openness (M2/GDP), and macroeconomic stability (central government revenues /GDP) affect economic growth in a positive way. The results of the analysis show that institutions, openness and macroeconomic stability in middle income countries contribute to economic growth but that the level of this contribution is low.
\end{abstract}

Keywords: Economic Growth, Institutions, Openness, Macroeconomic Stability, Middle Income Countries, Panel Data Analysis

Jel Classification: C33, O40, O43, O50

\begin{abstract}
Özet
$\mathrm{Bu}$ çalışmanın amacı, 48 orta gelirli ülkede kurumlar, ticari-finansal dışa açıklık ve makroekonomik istikrar şeklindeki dolaylı belirleyicilerin ekonomik büyüme üzerindeki etkilerini incelemektir. Bu amaçla, 2002-2011 dönemi için söz konusu değişkenlere ait toplam on göstergenin ekonomik büyüme üzerindeki etkileri panel veri analizleri kullanılarak ekonometrik açıdan analiz edilmektedir. Analiz sonuçlarına göre, kurumlar (politik istikrar ve şiddetin yokluğu, düzenlemelerin kalitesi ve hukukun üstünlüğü), ticari ve finansal dişa açıklık (M2/GDP) ve makroekonomik istikrar (merkezi hükümet gelirleri/GDP) ekonomik büyümeyi pozitif yönlü etkilemektedirler. Analiz sonuçları orta gelirli ülkelerde; kurumlar, dışa açıklık ve makroekonomik istikrarın ekonomik büyümenin sağlanmasına katkıda bulunduklarını, ancak bu katkıların düzeyinin düşük olduğunu göstermektedir.
\end{abstract}

Anahtar Kelimeler: Ekonomik Büyüme, Kurumlar, Dışa Açıklık, Makroekonomik İstikrar, Orta Gelirli Ülkeler, Panel Veri Analizi

\footnotetext{
${ }^{1}$ This study has been produced from the doctoral thesis with the title of "Indirect Determinants of Economic Growth: A Panel Data Analysis on Middle Income Countries" by Fatih KAPLAN in 2013, with the consultancy of Assoc. Prof. Dr. Sevda YAPRAKLI.

* Assist. Prof. Dr ., Mersin University School of Applied Technology and Management, Department of International Trade and Logistics, fatihkaplan@mersin.edu.tr (Corresponding Author)

** Prof. Dr., Atatürk University Faculty of Economics and Administrative Sciences, Department of Economics, sevda1@atauni.edu.tr
} 


\section{Introduction}

The factors affecting economic growth and the causes of the differences of development level between countries constitute one of the important matters of debate of the literature of growth. By the time the 1990s, the economists of growth gave different answers to the question of why some countries had a higher growth rate than the others, that is, which factors affected economic growth. Within this context, the level of per capita output of the countries which had some economic factors such as real capital, labour force, natural resource, human capital, and technology was accepted to be high that much. But in the 1960s, it was tried to be replied why the aforesaid factors were inadequate in some countries and the various sides of the factors affecting economic growth were discussed. It can be said that the decrease of interest towards the traditional determinants, absence of convergence between the developed and developing countries, and theoretical-econometric developments are among the most important causes of discussing the various sides in economic growth theories.

From the mid-1990s on, both theoretical and applied studies, there has been a transition from the traditional economic factors to those indirectly affecting economic performance. This process of transition observed in economic growth literature led the determinants of economic growth to be divided into two groups. In this sense, while traditional economic factors were the direct determinants of growth, the items indirectly affecting economic growth, by affecting the direct determinants of economic growth, were described as the indirect determinants of economic growth (Temple, 1999; Rodrik ,2002; Unsal, 2007). These developments made the place and importance of institutions, openness and macroeconomic stability in the process of economic growth one of the basic areas of interests of both academicians and policymakers (Snowdon and Vane, 2005).

It is accepted that institutions, openness and macroeconomic stability are the locomotive power of economic development, which also includes economic growth, and that the improvements of the aforesaid factors can create massive increase in per capita income (Rodrik, 2002; Bloch and Tang, 2004, Snowdon and Vane, 2005). Within this framework, 
active institutions and corporate structure, trade and financial openness, and macroeconomic stability affect long-term economic growth, by removing market distortions, creating positive externalities, decreasing uncertainty and being effective on transaction costs, gathering financial resources, and easing technological information transfer (Fischer, 1993; King and Levine, 1993; Acemoglu, Johnson and Robinson, 2005; Kong, 2007). For these reasons, many economists have dealt with the various indicators of the indirect determinants and examined their effects on economic performance.

One major motivation of this study, which is made with reference to the important role that the indirect determinants play on economic growth, is to evaluate the impact of institutions, openness and macroeconomic stability on economic growth in 48 middle income countries with econometric methods. The rest of the paper is structured as follows. In Section 2 we present a brief overview of the relationship between the indirect determinants and economic growth, followed in Section 3 by a short review of the literature on the relationship between the indirect determinants and economic growth. Section 4 presents the description of theoretical framework and data set, the methodology used is discussed, the empirical evidence is presented. Section 5 concluding remarks are presented.

\section{The Relationship Between the Indirect Determinants and Economic Growth}

From the 1990s on, in line with the developments in the growth literature, it has been come to an agreement about that economic growth has been affected by a number of traditional factors such as real capital, labour force, natural resources, human capital, and technology as well as some other factors such as population increase, institutions, openness, macroeconomic stability, income inequality, geography, and political economy. By affecting the traditional factors, those factors creating a highly impact on economic growth, have been described as the indirect (basic) determinants of growth (Temple, 1999; Snowdon and Vane, 2005; Unsal, 2007). The effects of institutions, openness and macroeconomic stability, which are among the indirect determinants of economic growth, on economic performance are higher than those of the other indirect determinants. The developments of these factors become meaningful within the process of economic growth, by contributing to both the development of other factors and increase of productivity. 
While institutions, one of the basic indirect determinants, involve the issues of property rights, role of the laws, the impact of culture-norms and religion on individuals, and the process of individually decision making; the organisation and structure contains the governance of economic activities such as financial institutions or labour market institutions, and organization (Kong, 2007). It is accepted that the developments in institutions and institutional structure contribute to economic growth, by providing the use of resources effectively, increasing real and human capital accumulation, enabling the development of sociopolitical-cultural structure, and decreasing transaction costs (Acemoğlu et al., 2005; Putnam, 1993; Knack and Keefer, 1997; Easterly, 2001). Accordingly, institutions can affect economic performance to the extent that they can affect the production possibilities curve.

Openness includes trade and financial openness. Trade openness expresses the approach which aims to provide free trade together with the removal of state control on the trade of goods and services. Financial openness is a body of policies which targets first to remove the intervention and control of state on domestic banking and other financial tools, and which, then, intends the integration of domestic financial market into international markets (Yaprakl1, 2007). Trade openness affects economic growth not only through absolute and/or comparative advantage but also through some channels such as learning by practicing, specialization and knowledge overflowing, information transfer, research and development activities, and effect of level. According to the model used in applied literature related to the subject and the trade policies of the country in question, the effects of these channels on economic growth can be positive, negative or indefinite (Kong, 2007; Bloch and Tang, 2004). The effect of financial openness on growth is carried out through the removal of the restrictive effect of domestic saving limit on investment by drawing foreign capital, increasing financial intermediary services, and providing technological innovation (King and Levine, 1993).

Macroeconomic stability, which states economic situation that the stability is provided in monetary-fiscal policy and balance of payments, involves a low and predictable inflation rate, suitable real interest rate, a stabil and sustainable fiscal policy, a competitive and predictable exchange rate, and a reasonable balance of payments. Macroeconomic stability contributes to provide efficiency in price mechanism by removing the elements 
which causes uncertainty in macroeconomic factors, and to the increase of economic growth rate by providing possibility the increasing of investments and productivity (Fischer, 1993).

\section{Literature}

In the applied studies related to the relationship between the indirect determinants and economic growth in the international literature, it is observed that a standard and extensive measurement of indirect determinant has not been used. However, it is seen to have been benefited from a number of indicators of the indirect determinants in theoretical and applied studies. The literature summary related to the basic applied studies made in various years between 1995-2012 is presented in the Table 3.1.

Table 3.1. The Literature Summary Related to the Relationship between the Indirect

Determinants and Economic Growth

\begin{tabular}{|c|c|c|c|c|c|}
\hline & $\begin{array}{l}\text { Writer(s)/ } \\
\text { Study Year }\end{array}$ & Countries & Term & Method & Result \\
\hline \multirow{13}{*}{ 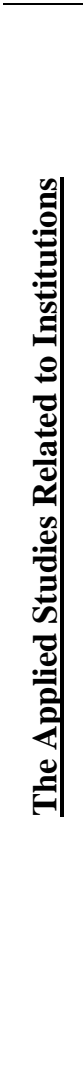 } & $\begin{array}{l}\text { Helliwell- } \\
\text { Putnam/1995 }\end{array}$ & Italy & $1960-1970$ & OLS & Doesn't affect economic growth. \\
\hline & Rodrik/1999 & $\begin{array}{l}97 \mathrm{HIC} \text { and } \\
\text { MIC }\end{array}$ & $\begin{array}{l}1960-1975 \\
1975-1989\end{array}$ & OLS & $\begin{array}{l}\text { Positively affects economic } \\
\text { growth. }\end{array}$ \\
\hline & $\begin{array}{l}\text { Zak and } \\
\text { Knack/2001 }\end{array}$ & 41 Countries & 2001 & OLS & $\begin{array}{l}\text { Positively affects economic } \\
\text { growth. }\end{array}$ \\
\hline & Tavares/2004 & Portugal & 1960-1995 & OLS & $\begin{array}{l}\text { Positively affects economic } \\
\text { growth. }\end{array}$ \\
\hline & Glaeser et al./2004 & 72 Countries & $1960-2000$ & OLS & $\begin{array}{l}\text { Positively affects economic } \\
\text { growth. }\end{array}$ \\
\hline & $\begin{array}{l}\text { Easterly et } \\
\text { al./2006 }\end{array}$ & $\begin{array}{l}82 \mathrm{HIC} \text { and } \\
\mathrm{MIC}\end{array}$ & 1960-1990 & $3 \mathrm{SLS}$ & $\begin{array}{l}\text { Positively affect economic } \\
\text { growth. }\end{array}$ \\
\hline & Vural/2007 & $\begin{array}{l}14 \text { EU } \\
\text { Countries and } \\
\text { Turkey }\end{array}$ & $1990-2000$ & OLS & $\begin{array}{l}\text { Affects economic growth in the } \\
\text { form of }(\mathrm{U}) \text {. }\end{array}$ \\
\hline & Yaprakl1/2008 & $36 \mathrm{MIC}$ & 2002-2005 & OLS & $\begin{array}{l}\text { Institutional structure is the result } \\
\text { of economic growth. }\end{array}$ \\
\hline & $\begin{array}{l}\text { Cavalcanti et } \\
\text { al./2008 }\end{array}$ & Brazil & $1960-2000$ & $2 \mathrm{SL}$ & $\begin{array}{l}\text { Positively affects economic } \\
\text { growth. }\end{array}$ \\
\hline & $\begin{array}{l}\text { Beşkaya and } \\
\text { Manas/2009 }\end{array}$ & Turkey & $1970-2005$ & OLS & $\begin{array}{l}\text { Its effect on economic growth is } \\
\text { uncertain. }\end{array}$ \\
\hline & Libman/2010 & Russia & 2000-2004 & OLS & $\begin{array}{l}\text { Negatively affects if not in } \\
\text { optimal level. }\end{array}$ \\
\hline & $\begin{array}{l}\text { Özkan and Tarı } \\
\text { /2011 }\end{array}$ & Turkey & 1987-2008 & OLS & $\begin{array}{l}\text { Positively affects economic } \\
\text { growth. }\end{array}$ \\
\hline & $\begin{array}{l}\text { Alfano and } \\
\text { Baraldi/2011 }\end{array}$ & Italy & 1980-2008 & GMM & $\begin{array}{l}\text { Positively affects economic } \\
\text { growth. }\end{array}$ \\
\hline \multirow{2}{*}{ 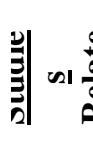 } & $\begin{array}{l}\text { Sachs and } \\
\text { Warner/1995 }\end{array}$ & $\begin{array}{l}37 \mathrm{HIC} \text { and } \\
\mathrm{MIC}\end{array}$ & 1970-1989 & OLS & $\begin{array}{l}\text { Trade openness positively affects } \\
\text { economic growth. }\end{array}$ \\
\hline & Kwan et al./1998 & $\begin{array}{l}4 \text { Asian } \\
\text { countries }\end{array}$ & 1962-1995 & OLS & $\begin{array}{l}\text { Financial openness positively } \\
\text { affects economic growth. }\end{array}$ \\
\hline
\end{tabular}




\begin{tabular}{lllll}
$\begin{array}{l}\text { Rodriguez and } \\
\text { Rodrik/2000 }\end{array}$ & $\begin{array}{l}\text { 95 countries- } \\
71 \text { countries }\end{array}$ & $\begin{array}{l}1976-1985 \\
1970-1989\end{array}$ & OLS & $\begin{array}{l}\text { Trade openness doesn't affect } \\
\text { economic growth. }\end{array}$ \\
\hline $\begin{array}{l}\text { Guillaumet and } \\
\text { Richaud/2001 }\end{array}$ & France & $1850-1997$ & OLS & $\begin{array}{l}\text { The effect of trade openness on } \\
\text { economic growth is uncertain. }\end{array}$ \\
\hline $\begin{array}{l}\text { Din et al./2003 } \\
\begin{array}{l}\text { Ogujiuba et } \\
\text { al./2004 }\end{array}\end{array}$ Pakistan & $1960-2001$ & VECM & $\begin{array}{l}\text { Trade openness doesn't affect } \\
\text { economic growth. }\end{array}$ \\
\hline $\begin{array}{l}\text { Utkulu and } \\
\text { Kahyaoğlu/2005 }\end{array}$ & Turkey & $1980-2003$ & $\begin{array}{l}\text { Co- } \\
\text { integration }\end{array}$ & $\begin{array}{l}\text { Trade openness doesn't affect } \\
\text { economic growth. }\end{array}$ \\
\hline $\begin{array}{l}\text { Yaprakli/2007 } \\
\text { Turkey }\end{array}$ & $1990-2004$ & $\begin{array}{l}\text { TAR, } \\
\text { STAR and } \\
\text { Markow }\end{array}$ & $\begin{array}{l}\text { Economic growth is affected } \\
\text { positively by trade openness. }\end{array}$ \\
\hline $\begin{array}{l}\text { Bashar and } \\
\text { Khan/2007 }\end{array}$ & Bangladesh & $1974-2002$ & $\begin{array}{l}\text { Co- } \\
\text { integration } \\
\text { integration }\end{array}$ & $\begin{array}{l}\text { Economic growth is affected } \\
\text { positively by trade openness and } \\
\text { negatively by financial openness. }\end{array}$ \\
\hline $\begin{array}{l}\text { Korkmaz et } \\
\text { al./2010 }\end{array}$ & Turkey & $1990-2008$ & $\begin{array}{l}\text { Economic growth is partially } \\
\text { related with financial openness } \\
\text { and is unrelated with trade } \\
\text { openness. }\end{array}$ \\
\hline
\end{tabular}

Table 3.1. (cont.)

\begin{tabular}{|c|c|c|c|c|c|}
\hline & $\begin{array}{l}\text { Writer(s)/ } \\
\text { Study year }\end{array}$ & Countries & Term & Method & Result \\
\hline & $\begin{array}{l}\text { Huang and } \\
\text { Wang/2010 }\end{array}$ & China & $1997-2008$ & OLS & $\begin{array}{l}\text { Financial openness positively } \\
\text { affects economic growth. }\end{array}$ \\
\hline & Faria/2011 & Brazil & 1990-2007 & VAR & $\begin{array}{l}\text { Financial openness partially } \\
\text { affects economic growth. }\end{array}$ \\
\hline & Mougani/2012 & 64 Countries & 1976-2009 & $\begin{array}{l}\text { OLS, } \\
\text { GMM }\end{array}$ & $\begin{array}{l}\text { Financial openness positively } \\
\text { affects economic growth. }\end{array}$ \\
\hline \multirow{9}{*}{ 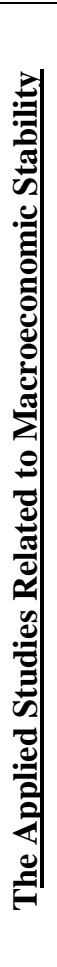 } & Barro/1996 & 100 Countries & $1960-1990$ & OLS & $\begin{array}{l}\text { Inflation uncertainty negatively } \\
\text { affects economic growth. }\end{array}$ \\
\hline & $\mathrm{Ma} / 1998$ & Colombia & $\begin{array}{l}1955-1997 \\
1977-1997 \\
\end{array}$ & VAR & $\begin{array}{l}\text { Inflation uncertainty negatively } \\
\text { affects economic growth. }\end{array}$ \\
\hline & $\begin{array}{l}\text { Domaç and } \\
\text { Shabsigh/1999 }\end{array}$ & $\begin{array}{l}4 \text { Middle East } \\
\text { Countries }\end{array}$ & $1970-1995$ & OLS & $\begin{array}{l}\text { Exchange rate uncertainty } \\
\text { negatively affects economic } \\
\text { growth. }\end{array}$ \\
\hline & Crosby/2000 & Hong Kong & 1974-1999 & OLS & $\begin{array}{l}\text { Economic growth is affected } \\
\text { positively by interest and inflation } \\
\text { uncertainty. }\end{array}$ \\
\hline & $\begin{array}{l}\text { Nas and } \\
\text { Perry/2001 }\end{array}$ & Turkey & 1963-1999 & GARCH & $\begin{array}{l}\text { Inflation uncertainty negatively } \\
\text { affects economic growth. }\end{array}$ \\
\hline & $\begin{array}{l}\text { Keşkek and } \\
\text { Özhan/2004 }\end{array}$ & Turkey & $1950-2002$ & GARCH & $\begin{array}{l}\text { Inflation uncertainty negatively } \\
\text { affects economic growth. }\end{array}$ \\
\hline & Ismihan et al./2005 & Turkey & 1963-1999 & $\begin{array}{l}\text { Co- } \\
\text { integration } \\
\text { VAR }\end{array}$ & $\begin{array}{l}\text { Negatively affects economic } \\
\text { growth. }\end{array}$ \\
\hline & Lensink/2005 & 138 Countries & $1970-1995$ & OLS & $\begin{array}{l}\text { Instability negatively affects } \\
\text { economic growth in developing } \\
\text { countries and positively in } \\
\text { developed countries. }\end{array}$ \\
\hline & Fountas et al./2006 & $\begin{array}{l}7 \text { Developed } \\
\text { Countries }\end{array}$ & $1957-2000$ & OLS & $\begin{array}{l}\text { Inflation and output uncertainty } \\
\text { negatively affects economic } \\
\text { growth. }\end{array}$ \\
\hline
\end{tabular}




\begin{tabular}{lllll}
\hline Schnabl/2007 & 41 Countries & $1994-2005$ & GLS & $\begin{array}{l}\text { The effect of instability on growth } \\
\text { is depend on development level. }\end{array}$ \\
\hline Adak/2010 & Turkey & $1972-2006$ & OLS & $\begin{array}{l}\text { Budget uncertainty negatively } \\
\text { affects economic growth. }\end{array}$ \\
\hline $\begin{array}{l}\text { Mahmood et } \\
\text { al./2011 }\end{array}$ & Pakistan & $1975-2005$ & $\begin{array}{l}\text { GARCH } \\
\text { OLS }\end{array}$ & $\begin{array}{l}\text { Exchange rate uncertainty } \\
\text { positively affects economic } \\
\text { growth. }\end{array}$ \\
\hline
\end{tabular}

In conclusion, the different aspects of the relationship between the indirect determinants and economic growth can be said to be generally examined through panel and cross-sectional data analysis in applied studies. The basic common point of the aforesaid studies, which complete each other, is that they have achieved the result that the positive effect of the indirect determinants on economic growth shows increase together with development level.

Comparing with other studies made on middle income countries, it is possible to state that this study is different in the sense of the term of the data, the consolidation of theoretical and applied literature, and econometric method. Besides, with reference to the results of the study, the policy offers suggested are expected to provide benefit for the actors who both follow an economy policy and are affected by economy policy.

\section{Theoretical Framework and Data Set}

The data belonging to the term of 2002-2011 are used in the estimation of the effect of institutions, openness and macroeconomic stability on economic growth in this study. That the term discussed in the study is limited derives from the difficulty of finding data about the indicators of the indirect determinants. In considering GDP for economic growth ${ }^{2}$, it has been effective that GDP shows the level of life standard in an economy (King and Levine, 1993; Knack and Keefer, 1997). The data of GDP, which has been compiled in the local currency of middle income ${ }^{3}$ countries $^{4}$, has been calculated in dollar by dividing into average nominal USA exchange rate of dollar.

\footnotetext{
${ }^{2}$ The data of the application are constituted by, on behalf of economic growth, the variables related to gross domestic product (GDP) per capita, the indicators of corporate structure, trade and financial openness, and macroeconomic stability.

${ }^{3}$ The level of per capita income of which is between 1026-12475 $\$$ in the ranking made by the World Bank according to the gross domestic product (GDP) in 2011

${ }^{4}$ Angola, Argentina, Albania, Azerbaijan, Belarus, Bolivia, Brazil, Bulgaria, China, Dominican Republic, Ecuador, El Salvador, Indonesia, Armenia, Morocco, Philippines, Ghana, Guatemala, South Africa, Georgia, Honduras, Kazakhstan, Colombia, Costa Rica, Lesotho, Latvia, Lithuania, Macedonia, Malaysia, Mexico, Egypt, Mongolia, Moldova, Namibia, Nicaragua, Pakistan, Panama, Paraguay, Peru, Romania, Russia, Sri Lanka, Tunisia, Turkey, Ukraine, Uruguay, Jordan, and Vietnam.
} 
In respect of institutions, the indicators such political stability and absence of violence, government effectiveness, regulatory quality and the rule of law. These indicators are calculated by international organizations, which have a high credibility, and are used very often in the applied literature. Institutional structure indicators including subjectivity at a certain level are composed of indexes and the maximum value of indexes is " 100 " and the minimum is " 0 ". That the value of indexes is high means the effectiveness of corporate structure is also high.

Some variables such as (import+export/GDP) for trade openness, monetary quantity described as M2/GDP, and private capital flows to GDP ratio have been used. The variables of inflation rate, current account to GDP ratio, and central government revenues to GDP ratio have been used as the indicator of macroeconomic stability. The inflation rate has been calculated according to the consumer price index of the year 2005.

While compiling the data, the statistics of the World Bank, the World Bank (Worldwide Governance Indicators-WGI), International Monetary Fund (IMF), and IMF World Economic Outlook (WEO) have been benefited from.

\subsection{Method}

In the study, the production function, which is commonly used in the applied literature and which has been developed by Rodrik, Subramanian and Trebbi (2002) model is as the following:

$$
\ln \mathrm{GDP}=\mathrm{c}+\beta \mathrm{X}
$$

In the model numbered (4.1), ln represents logarithm, GDP represents real gross domestic product per capita, c represents constant term, and X represents other factors. In the study, the indirect determinants for the $(\mathrm{X})$ variable have been added as independent variables and a model has been generated for each indirect determinant. Thus, the variables related to the indirect determinants such as institutions, trade and financial openness and macroeconomic stability have been subjected to regression analysis. The growth models predicted in the study are as below: 
The Impacts of Instıtutions, Openness and Macroeconomic Stability on Economic Growth

$$
\operatorname{lnGDP} P_{\text {it }}=c_{0}+\alpha_{1} \text { PSAAV }_{\text {it }}+\alpha_{2} \mathrm{GF}_{\text {it }}+\alpha_{3} \mathrm{RQ}_{\mathrm{it}}+\alpha_{4} \mathrm{ROL}_{\mathrm{it}}+\varepsilon_{\mathrm{it}}
$$

In the model numbered (4.2), for the $(\mathrm{X})$ variable, the explanatory variables belonging to institutions such as PSAAV (political stability and absence of violence), GF (government effectiveness), RQ (the regulatory quality), and ROL (the rule of law) are used.

$$
\operatorname{lnGDP} P_{\text {it }}=c_{0}+\beta_{1} \operatorname{lnM}_{2} \mathrm{GDP}_{\mathrm{it}}+\beta_{2} \text { FFLOW }_{\mathrm{it}}+\beta_{3} \operatorname{lnOTRADE}_{\mathrm{it}}+\varepsilon_{\mathrm{it}}
$$

In the model numbered (4.3), for the $(\mathrm{X})$ variable, the explanatory variables belonging to trade and financial openness such as M2/GDP (financial openness), OTRADE (trade openness), and FFLOW (private capital flows) are used.

$$
\operatorname{lnGDP} P_{\text {it }}=c_{0}+\delta_{1} \mathrm{ENF}_{\mathrm{it}}+\delta_{2} \mathrm{BOPGDP}_{\mathrm{it}}+\delta_{3} \operatorname{lnREV}_{\mathrm{it}}+\varepsilon_{\mathrm{it}}
$$

In the model numbered (4.4), for the (X) variable, the explanatory variables belonging to macroeconomic stability such as ENF (inflation rate), BOP/GDP (current account balance/GDP), and REV (central government revenue) are used. In the three models mentioned above, $i$ represents the cross-sectional data, that is, countries $(i=1, \ldots, 48), t$ shows the term $(\mathrm{t}=2002-2011)$, and $\varepsilon$ represents the error term.

\subsection{Preliminary Analysis: Cross-section Dependency and Unit Root}

Before panel data analysis, one important issue to be considered to testing for crosssectional dependency across countries. In this case, the presence/absence of the correlation between the units is sought through Pesaran $\left(\mathrm{CD}_{\mathrm{LMadj}}\right)$, Friedman (FR), Frees (FRS) tests, which search cross-sectional dependence. If $\mathrm{H}_{0}$ hypothesis is rejected after $\mathrm{CD}_{\mathrm{LM}}, \mathrm{FR}$ and FRS tests, it is accepted that there is a cross-sectional dependence between the units.

For this purpose, Pesaran, Ullah and Yamagata (PUY, 2008). proposed the following Lagrange multiplier test statistic: $\mathrm{LM}_{\mathrm{adj}}=\sqrt{\frac{2}{\mathrm{~N}(\mathrm{~N}-1)}} \mathrm{T} \sum_{\mathrm{i}=1}^{\mathrm{N}-1} \sum_{\mathrm{j}=\mathrm{i}+1}^{\mathrm{N}} \frac{(\mathrm{T}-\mathrm{k}) \hat{\mathrm{P}}_{\mathrm{ij}}^{\mathrm{z}}-\mu_{\mathrm{Tij}}}{\sigma_{\mathrm{Tij}}}$. Friedman (1937) proposed a nonparametric test based on Spearman's rank correlation coefficient. Spearman's rank correlation coefficient equals, $F R=\left[(T-1)\left((N-1) R_{A V E}+1\right)\right]$. Frees 
(1995, 2004) proposed different statistic and the squared rank correlation coefficients and equals, $\mathrm{FRE}=\mathrm{N}\left(\mathrm{R}_{\mathrm{AVE}}^{2}-(\mathrm{T}-1)^{-1}\right)$.

Whether the panel data are stationary or not is searched through the $2^{\text {nd }}$ generation unit root tests, which consider cross-sectional dependence, since the asymptotic features of the $1^{\text {st }}$ generation unit root tests are negatively affected by cross-sectional dependence. Among the $2^{\text {nd }}$ generation unit root tests, Pesaran's CADF panel unit root test is suitable to the case of $\mathrm{N}>\mathrm{T}$. CADF test is the extended version of ADF unit root test with the first differences of the individual series and the cross-sectional average of the level of lagged (Pesaran, 2007).

\subsection{Robust Standard Errors Estimation with Cross-Sectional Dependence}

Classical, fixed and random effect regression models used in the panel data are based upon the assumption that there are not existence of the cross-sectional dependence, autocorrelation $^{5}$ and heteroscedasticity ${ }^{6}$. When the existence of these problems, the panel data model, which is estimated in accordance with the acceptance that there is no variance from the assumptions, must be purged of these problems and/or the adjusted model, which considers these problems, must be predicted. With this purpose, it is seen that Driscoll and Kraay estimator is often used in literature. Driscoll and Kraay estimator produces standard errors, which are consistent in the existence of heteroscedasticity that cross-sectional dimension, especially encountered in micro-econometric panels, is bigger than the time dimension, and which are resistant in the existence of cross-sectional dependence and autocorrelation (Driscoll and Kraay, 1998; Hoechle, 2007).

Finally, Stata 12 software and econometric analysis package program of Eviews 7.2 are used while making panel data analyses in this study ${ }^{7}$.

\footnotetext{
${ }^{5}$ See Baltagi (2005)

${ }^{6}$ See Brown and Forsythe (1974), Greene (2003).

${ }^{7}$ We thank Mrs. Assoc. Prof. Dr. Ferda Y. Tatoğlu for sharing Stata 12 codes with us. See Tatoğlu (2012)
} 
The Impacts of Instıtutions, Openness and Macroeconomic Stability on Economic Growth

\subsection{Empirical Results}

In the study, therefore, it has been searched if there is a correlation between the units through $\mathrm{CD}_{\mathrm{LMadj}}$, FR, and FRS tests, which analyze cross-sectional dependence, and the results obtained have been given in Table 4.1.

Table 4.1. Cross-Sectional Dependence Test Results

\begin{tabular}{|c|c|c|c|}
\hline & CD $_{\text {LM }}$ Test & FR Test & FRS Test \\
\hline (4.2) No. Model & $84,416^{\mathrm{a}}$ & $336,495^{\mathrm{a}}$ & $27,901^{\mathrm{a}}$ \\
\hline (4.3) No. Model & $62,14^{a}$ & $239,709^{a}$ & $15,182^{\mathrm{a}}$ \\
\hline (4.4) No. Model & $65,561^{\mathrm{a}}$ & $261,155^{\mathrm{a}}$ & $17,901^{\mathrm{a}}$ \\
\hline
\end{tabular}

Note: $\mathrm{a}, \mathrm{b}$ and $\mathrm{c}$ show the importance level of $1 \%, 5 \%$ and $10 \%$ respectively. Schwarz Information Criterion (SIC) has been used for optimal lag length.

As seen in Table 4.2, in consequence of $\mathrm{CD}_{\mathrm{LM}}$, FR and FRS tests, the hypothesis of $\mathrm{H}_{0}$, which suggest that there is no cross-sectional dependence between the units, has been rejected at the level of importance of $1 \%$. Hence, Pesaran's CADF unit root test, which internalizes cross-sectional dependence, and which is among the estimators called as $2^{\text {nd }}$ generation unit root tests has been applied to the variables used. This test provides to avoid from the unnecessary effects of possible en results that could occur in T samples (Pesaran 2007). The results belonging to CADF unit root test are as in the Table 4.2.

Table 4.2. Unit Root Test Results

\begin{tabular}{llc}
\hline \multirow{2}{*}{ Variables } & \multicolumn{2}{c}{ CADF } \\
\cline { 2 - 3 } lnGDP & Constant & Constant and Trend \\
\hline PSAAV & $-2,993^{\mathrm{a}}$ & $-3,362^{\mathrm{a}}$ \\
\hline GF & $-2,125^{\mathrm{a}}$ & $-2,745^{\mathrm{a}}$ \\
\hline RQ & $-4,723^{\mathrm{a}}$ & $-5,133^{\mathrm{a}}$ \\
\hline ROL & $-3,134^{\mathrm{a}}$ & $-3,124^{\mathrm{a}}$ \\
\hline $\operatorname{lnM} /$ GDP & $-4,127^{\mathrm{a}}$ & $-4,687^{\mathrm{a}}$ \\
\hline FFLOW & $-2,351^{\mathrm{a}}$ & $-2,578^{\mathrm{a}}$ \\
\hline $\operatorname{lnOTRADE}$ & $-4,321^{\mathrm{a}}$ & $-5,331^{\mathrm{a}}$ \\
\hline ENF & $-3,212^{\mathrm{a}}$ & $-3,512^{\mathrm{a}}$ \\
\hline BOP/GDP & $-3,236^{\mathrm{a}}$ & $-4,216^{\mathrm{a}}$ \\
\hline $\ln \mathrm{aEV}$ & $-2,956^{\mathrm{a}}$ & $-2,296^{\mathrm{a}}$ \\
\hline
\end{tabular}

Note: $a, b$ and c show the importance level of $1 \%, 5 \%$ and $10 \%$ respectively. Schwarz Information Criterion (SIC) has been used for optimal lag length. The critical values have been provided from Table C in Pesaran's (2007) article. 
As seen in Table 4.3, according to the CADF test, it has been established that all of the variables held in the study have become stationary with their levels [1(0)], that is, they have not had unit roots.

Since deviating from the assumptions of cross-sectional dependence, heteroscedasticities and autocorrelation would cause variance-covariance matrix of error terms to lose its feature of being unit matrix, the models have been adjusted by using Driscoll and Kraay Estimator and re-estimated by resistant estimators. The results of fixed effect model estimation are presented in Table $4.3^{8}$.

Table 4.3. Fixed Effect Model Estimation ${ }^{9}$

\begin{tabular}{|c|c|c|c|c|c|}
\hline No. & Variables & Parameter & Standard Error & t-statistic & Prob. \\
\hline \multirow{6}{*}{ 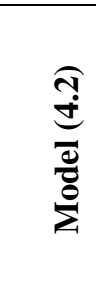 } & PSAAV & $0,0072^{\mathrm{a}}$ & 0,0016 & 4,57 & 0,000 \\
\hline & GF & $-0,0061^{b}$ & 0,0027 & $-2,26$ & 0,029 \\
\hline & $\mathbf{R Q}$ & $0,0241^{\mathrm{a}}$ & 0,0033 & 7,38 & 0,000 \\
\hline & ROL & $0,0092^{b}$ & 0,0039 & 2,34 & 0,024 \\
\hline & Cons & $6,3634^{\mathrm{a}}$ & 0,2035 & 31,26 & 0,000 \\
\hline & & 0,1458 & \multicolumn{3}{|c|}{ F sta. (p-value): $11,56(0,000)$} \\
\hline \multirow{5}{*}{ 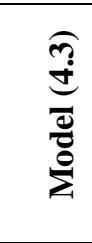 } & $\operatorname{lnM2/GDP}$ & $1,7226^{\mathrm{a}}$ & 0,1527 & 11,27 & 0,000 \\
\hline & FFLOW & $-0,0060^{\mathrm{a}}$ & 0,0024 & $-2,48$ & 0,011 \\
\hline & InOTRADE & $-0,5870^{a}$ & 0,2038 & $-2,88$ & 0,006 \\
\hline & Cons & $3,9185^{\mathrm{a}}$ & 1,2329 & 3,18 & 0,003 \\
\hline & & $\begin{array}{ll}\mathrm{R}^{2} & 0,49 \\
\end{array}$ & \multicolumn{3}{|c|}{ F sta. (p-value): $12,64(0,000)$} \\
\hline \multirow{5}{*}{ 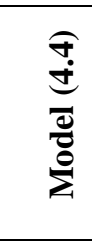 } & ENF & $-0,0128^{a}$ & 0,0023 & $-5,5003$ & 0,0000 \\
\hline & BOP/GDP & $-0,0078^{\mathrm{a}}$ & 0,0028 & $-2,7383$ & 0,0064 \\
\hline & lnREV & $1,9547^{\mathrm{a}}$ & 0,1743 & 11,2145 & 0,0000 \\
\hline & Cons & $1,5871^{\mathrm{a}}$ & 0,5709 & 2,7801 & 0,0057 \\
\hline & & $\mathrm{R}^{2} 0,2823$ & F sta. (p-value & $14(0,0000)$ & \\
\hline
\end{tabular}

According to the results of fixed effect panel data regression analysis, the parameters of the all variables are statistically meaningful. The statistical value of $\mathrm{F}$ shows that all models, as a whole, is meaningful at the importance level of $1 \%$. According to the results, for the model numbered (4.2), it is possible to say that the effect of institutions on economic growth in middle income countries is very low. For the model numbered (4.3), It is possible to say that the effect of trade and financing on economic growth in middle income countries,

\footnotetext{
${ }^{8}$ The results of $\mathrm{F}$ and LR tests, unit effects exist in significance levels of $1 \%$ in all models. The results of Hausman Test and Mundlak Test, one-way (unit effect) fixed effect models must be predicted. All models have been estimated in one-way (unit effect) fixed effect model. But, cross-sectional dependence (correlation between the units), autocorrelation, and heteroscedasticity have been observed. So, Driscoll and Kraay Estimator has been used.
} 
except for the variable of FFLOW, is higher than the institutional indicators. For the model numbered (4.4), It is possible to say that the effect of macroeconomic stability/instability on economic growth in middle income countries, except for the variable of $\operatorname{lnREV}$, is very low and negative.

\section{Conclusion}

In this study, the effects of the indirect determinants such as institutions, openness, and macroeconomic stability in 48 middle income countries on economic growth has been econometrically analyzed, by using panel data belonging to the term of 2002-2011. With this purpose, the fixed-effects regression with Driscoll and Kraay standard errors are benefited from.

According to the results of fixed effect model estimation, in middle income countries, which include also Turkey, of the indicators related to institutions, political stability and absence of violence, the regulatory quality and the rule of law positively affect the growth and the government effectiveness affects it negatively. As to openness, while the effects of trade openness and the variable of M2/GDP on growth are negative, those of private capital flows/GDP are positive. Of macroeconomic stability indicators, the effects of inflation and current account balance/GDP on economic growth are negative, central government revenue/GDP is positive. The results of the analysis show that institutions, openness, and macroeconomic stability contribute to economic growth in middle income countries, but the level of this contribution is low.

Though the positive effects of the indirect determinants on economic growth are small, that the indirect determinants in middle income countries catch the trend of a continuous and steady growth together with the direct determinants are among the important cases which can approach middle income countries to high income countries. To do this, it is required to give importance political measures to improve the indirect determinants as well as the direct determinants, in terms of economic growth in middle income countries trying to keep up with the improvements in the world economy. Within this framework, for institutions and trade

\footnotetext{
${ }^{9}$ The Correlation analysis has been made for the relationship between the term error and independent variables, it has been established that there has been no problem of internality in models.
} 
and financial openness, some measurements such as making formal institutional arrangements functional and carrying out formal and informal institutional arrangements in line with each other, providing emission of money in accordance with GDP increases, improving some policies such as increasing exports or improving policies that incent international private capital flows are needed. Some measurements must be appealed such as steady inflation rates, balanced current account balance, and concentrating on policy measurements which can provide high public revenue for macroeconomic stability. In addition to this, it is possible to say that comprising aggregative index which involves the indicators that represent the indirect determinants would contribute to get more meaningful results for the applied studies to be made in the future.

\section{References}

Acemoglu, D., Johnson, S. and Robinson A.J. 2005. Institutions as the Fundamental Cause of Long-Run Growth. Ed. Aghion, P. and Durlauf, S.N. Handbook of Economic Growth, Elsevier: 368-472.

Adak, M. 2010. Public Debt and Economic Growth: The Case of Turkey. Maliye Dergisi 159(2): 233-243.

Alfano, M. R. and Baraldi A. L. 2011. Political Competition and Economic Growth: Evidence from Italy. SSRN Working Paper,SSRN-id1751066.

Baltagi, H. B. 2005. Econometric Analysis of Panel Data, John Wiley Sons Inc., Chichester .

Barro, J. R..1996. Determinants of Growth: A Cross-Country Emprical Study. NBER Working Paper, No: 5698.

Bashar, K. M. R. O. and Khan, H. 2007. Liberalization and Growth: An Econometric Study of Bangladesh. U21Global Working Paper Series, No: 001/200. 
Beşkaya, A. ve Manan, O. 2009. A Time Series Analysis Of The Nexus Between Economic Freedom and Democracy And Economic Performance: The Turkish Case Zonguldak Karaelmas University, U Journal of Social Sciences 5(10): 47-76.

Bloch, H. and Tang, H.K. S. 2004. Deep Determinants of Economic Growth: Institutions, Geography and Openness to Trade. Progress in Development Studies 4(3): 245255.

Brown, B. M. and Forsythe, B. A. 1974. Robust Tests For Equality of Variances. Journal of the American Statistical Association 69(346): 364-367.

Cavalcanti, V. T., Magalh aes M. A. and Tavares, A. J. 2008. Institutions and Economic Development In Brazil. The Quarterly Review of Economics and Finance 48(2): $412-432$.

Crosby, M. 2000. Exchange Rate Volatility and Macroeconomic Performance in Hong Kong. Hong Kong Institute for Monetary Research Working Papers, No:032000.

Din, M., Ghani, E. and Siddique, O. 2003. Openness and Economic Growth in Pakistan. The Pakistan Development Review 42(4): 795-807.

Driscoll, J. C., and A. C. Kraay. 1998. Consistent Covariance Matrix Estimation with Spatially Dependent Panel Data. Review of Economics and Statistics, 80: 549-560.

Domaç, İ. and Shabsigh, G. 1999. Real Exchange Rate Behavior and Economic Growth: Evidence from Egypt, Jordan, Morocco, and Tunisia. IMF Working Paper, No: WP/99/40.

Easterly, W.2001. Can Institutions Resolve Ethnic Conflict?. Economic Development and Cultural Change 49(4): 687-706.

Easterly, W., Ritzan, J. and Woolcock, M. 2006. Social Cohesion, Institutions, and Growth. Economics \& Politics 18(2): 103-120. 
Faria , A. J., Paula, F., Luiz, P. ,C.C. Manoel and Meyer, R.T. 2011. Financial Liberalization, Economic Performance And Macroeconomic Stability in Brazil: An Assessment Of The Recent Period. 37th Brazilian Economics Meeting, Brazil.

Fischer, S.1993. The Role of Macroeconomic Factors in Growth. NBER Working Paper No. 4565.

Frees, E. 1995. Assessing cross-sectional correlation in panel data. Journal of Econometrics, 69: 393-414.

Frees E.W. 2004. "Longitudinal and Panel Data: Analysis and Applications in the Social Sciences", Cambridge University Press.

Friedman, M. 1937. The Use of Ranks to Avoid the Assumption of Normality Implicit in the Analysis of Variance. Journal of the American Statistical Association, 32: 675-701.

Fountas, S., Karanasos, M. and Kim, J. 2006. Inflation Uncertainty, Output Growth Uncertainty and Macroeconomic Performance. Oxford Bulletin of Economics and Statistics 68(3): 319-343.

Glaeser, L. E., Porta, L. R., Lopez-de-Silane, F. and Shleifer, A. 2004. Do Institutions Cause Growth?. Journal of Economic Growth 9(3): 271-303.

Greene, H. W. 2003. Econometric Analysis, Prentice Hall, New Jersey.

Guillaumet, P. and Richaud, A. 2001. Openness and Economic Growth: The Case of France Since 1850. VIth Spring Meeting of Young Economists.

Hausman, A. J. 1978. Specification Tests in Econometrics. Econometrica 46 :12511271. 
Helliwell, F. J. and Putnam D. R. 1995. Economic Growth and Social Capital in Italy. Eastern Economic Journal 21(3): 295-307.

Hoechle, D. 2007. "Robust Standard Errors for Panel Regressions with CrossSectional Dependence”, Stata Journal, 7:1-31.

Huang, Y. and Wang, X. 2010. Financial Repression and Economic Growth in China. China Growth Centre (CGC) Discussion Paper Series, No:5.

Ismihan, M., Metin-Ozcan, K. and Tansel, A. 2005. The Role Of Macroeconomic Instability in Public And Private Capital Accumulation And Growth: The Case Of Turkey 1963-1999. Applied Economics 37(2): 239-251.

Keşkek, S. ve Özhan, M. 2004. Inflation, Inflation Uncertainty and Economic Growth. Journal of Active, 37: 1-18.

King G. R. and Levine, R. 1993. Finance and Growth: Schumpeter Might Be Right. The Quarterly Journal of Economics 108(3): 717-733.

Knack, S. and Keefer, P. 1997. Does Social Capital Have an Economic Payoff? A Cross-Country Investigation. The Quarterly Journal of Economics 112(4): 1251-1288

Kong, T. 2007. A Selective Review of Recent Developments in the Economic Growth Literature. Asian-Pacific Economic Literature 21(1): 1-33.

Korkmaz, T., Çevik, İ. E. and Birkan, E. 2010. Financial Openness Impact on Economic Growth and Financial Crisis: The Case of Turkey. Journal of Yasar University 17(5): 2821-2831.

Kwan, C. C. Andy, Wu, Yangru and Zhang, Junxi. 1998. "An Exogeneity Analysis Of Financial Deepening And Economic Growth: Evidence From Hong Kong, South Korea And Taiwan." The Journal of International Trade \& Economic Development: An International and Comparative Review, 7(3): 339-354. 
Lensink, R. .2005. Uncertainty, Financial Development And Economic Growth: An Empirical Analysis. Organisations and Management (SOM), Researh Paper,No:187693.

Libman, A. 2010. Democracy, Size of Bureaucracy, and Economic Growth: Evidence from Russian Regions. Center for Doctoral Studies in Economics Discussion Paper, No:61.

Ma, H. 1998. Inflation, Uncertainty and Growth in Colombia. IMF Working Paper,No:WP/98/161.

Mahmood, I., Ehsanullah, M. and Ahmed, H. 2011. Exchange Rate Volatility and Macroeconomic Variables in Pakistan. Business Management Dynamics 1(2): 11-22.

Mougani, G. 2012. An Analysis of the Impact of Financial Integration on Economic Activity and Macroeconomic Volatility in Africa within the Financial Globalization Contexts. African Development Bank No:144.

Mundlak, Y. 1978. On the Pooling of Time Series and Cross Section Data. Econometrica, 46(1): 69-85.

Nas, F. T. and Perry, J. M. 2000. Inflation, Inflation Uncertainty and Monetary Policy in Turkey:1960-1998. Contemporary Economic Policy18(2): 170-180.

Pesaran, M. H. 2007. A Simple Panel Unit Root Test in the Presence of Cross Section Dependence. Journal of Applied Econometrics 22: 265-312.

Pesaran, M. Hashem,. A. Ullah and T. Yamagata. 2008. “A Bias-Adjusted LM Test of Error Cross-Section Independence," Econometrics Journal, Royal Economic Society, Vol. 11(1):105-127. 
Putnam, D. R. 1993. The Prosperous Community: Social Capital and Public Life. The American Prospect. http://xroads.virginia.edu/ HYPER/DETOC/assoc/13putn.html Erişim Tarihi: 13.10 .2012 .

Rodrik, D.1999. Where Did All the Growth Go? External Shocks, Social Conflict and Growth Collopses. Journal of Economic Growth, 4(4): 385-411.

Rodrik, D. 2002. Institutions, Integration, And Geography: In Search of The Deep Determinants of Economic Growth. An Introduction to an Edited Volume of Analytic Growth Narratives. http://www.wcfia.harvard.edu/node/588 Erișim Tarihi 20.04.2012.

Rodrik, D., A. Subramanian and Trebbi, F. 2004. “Institutions Rule: The Primacy of Institutions Over Geography and Integration in Economic Development", Journal of Economic Growth, 9(2):131-165.

Rodriguez, F. and Rodrik, D. 2000. Trade Policy and Economic Growth: A Skeptic's Guide to The Cross-National Evidence. NBER No:7081.

Sachs, J. and Warner, A. 1995. Economic Reform and The Process of Global Integration. Brooking Papers Of Economic Activity. 26(1): 1-118.

Schnabl, G. 2007. Exchange Rate Volatility and Growth in Small Open Economies at the EMU Periphery. European Central Bank Working Paper Series No:773.

Snowdon, B. and Vane, H. 2005. Modern Macroeconomics: Its Origins, Development And Current State, Edward Elgar Publishing, Cambridge.

Tavares, A. J. 2004. Institutions and Economic Growth in Portugal: A Quantitative Exploration. Portuguese Economic Journal 3(1): 49-79.

Temple, J. 1999. The New Growth Evidence. Journal of Economic Literature, 37(1): 112-156. 
Ogujiuba, K., Kanayo, O., O., George and Adenuga O. A. 2004. Is Trade Openness Valid for Nigeria's Long-Run Growth?: A Cointegration Approach. Central Bank of Nigeria Working Paper No: 0412009

Özkan, F. ve Tarı, R. 2011. The Impact of Legal and Institutional Reforms on Turkish Economy After 2001. Zonguldak Karaelmas University Journal of Social Sciences 7(14): 114.

Utkulu, U. ve Kahyaoğlu, H. 2005. Trade and financial openness affect to economic growth in which direction in Turkey. Turkish Economic Association.No:2005/13.

Unsal, M. Erdal (2007). Economic Growth. Imaj Press, Ankara.

Vural, M. B. 2007. Effect of Institutional Coordination on Economic Growth, Dokuz Eylül Universtiy Journal of Faculty of Busines8(1): 1-29.

Yaprakl1, S. 2007. The Relationship Between Trade and Financial Openness And Economic Growth: Evidence of Turkey. İstanbul University Journal of Econometrics and Statistics, 5: 67-89.

Yaprakl1, S. 2008. The Effect of Institutional Structure On Economic Growth: An Application For Upper-Middle Income Countries. Ege Academic Review 8(1): 301-307.

Zak, J. P. and Knack, S. 2001. Trust and Growth. The Economic Journal, 111( 470): 295-321. 